\title{
Penentuan Cluster Pengembangan Komoditas Unggulan Desa-Desa Tertinggal Di Kabupaten Bangkalan Berdasarkan Faktor-Faktor Yang Mempengaruhi
}

\author{
Ayu Nur Rohmawati, Eko Budi Santoso \\ Departemen Perencanaan Wilayah dan Kota, Fakultas Teknik Sipil dan Perencanaan, Institut \\ Teknologi Sepuluh Nopember (ITS) \\ e-mail: eko_budi@urplan.its.ac.id
}

\begin{abstract}
Abstrak - 32 dari 36 desa tertinggal di Kabupaten Bangkalan memiliki potensi produksi pertanian tanaman pangan yang bisa dikembangkan untuk meningkatkan kesejateraan masyarakat desa tertinggal yang rata-rata $51 \%$ penduduknya miskin. Untuk dapat mengembangkan potensi pertanian tersebut, dilakukan analisis terhadap faktor-faktor yang mempengaruhi pengembangan potensi pertanian desa-desa tertinggal di Kabupaten Bangkalan dengan menggunakan teknik analisis CFA. Hasil dari identifikasi faktor-faktor yang mempengaruhi tersebut digunakan sebagai input untuk melakukan pengelompokan (clustering) desa-desa tertinggal berdasarkan kondisi eksisting dari faktor-faktor yang mempengaruhi pengembangan potensi pertanian, dengan menggunakan analisis cluster. Pengelompokkan ini bertujuan untuk memberikan arahan yang sesuai dengan permasalahan dari masing-masing desa tertinggal terkait pengembangan potensi produksi komoditas unggulan berdasarkan clusternya. Berdasarkan hasil analisis, diketahui faktor-faktor yang mempengaruhi perkembangan potensi pertanian desa tertinggal di Kabupaten Bangkalan adalah potensi fisik, sumber daya manusia, prasarana produksi komoditas unggulan pertanian, teknologi pertanian, keterkaitan fungsional, kelembagaan, kemitraan dan modal. Sedangkan berdasarkan hasil analisis cluster terhadap kondisi eksisting dari masing-masing faktor tersebut, desa-desa tertinggal di Kabupaten Bangkalan terbagi ke dalam 3 cluster yaitu cluster I (desa tertinggal dengan perkembangan potensi pertanian sangat kurang berkembang), cluster II (desa tertinggal dengan perkembangan potensi pertanian kurang berkembang) sebanyak 16 desa dan cluster III (desa tertinggal dengan perkembangan potensi pertanian cukup berkembang).
\end{abstract}

Kata Kunci-desa tertinggal, potensi pertanian, cluster desa tertinggal, faktor pertanian.

\section{PENDAHULUAN}

$\mathrm{K}$ ABUPATEN Bangkalan merupakan salah satu daerah tertinggal di Indonesia berdasarkan peraturan presiden nomor 131 tahun 2015, yang memiliki 36 desa tertinggal yang tersebar di 16 dari 18 Kecamatan [1]. Tingkat kemiskinan di desa-desa tertinggal tersebut rata-rata sebesar $51 \%$ [2] sehingga untuk mengurangi tingkat kemiskinan dan meningkatkan kesejateraan masyarakat diperlukan pengembangan sektor ekonomi dominan yakni pertanian on farm sesuai dengan komoditas unggulannya masing-masing
[3]. 32 dari 36 desa tertinggal tersebut memiliki potensi pada kegiatan produksi pertanian (on farm) khususnya untuk komoditas tanaman pangan. Akan tetapi, kawasan pertanian di sebagian besar kecamatan-kecamatan dengan desa tertinggal yang ada di Kabupaten Bangkalan tersebut merupakan kecamatan dalam cluster II yaitu kawasan pertanian kurang berkembang karena memiliki skor yang rendah pada 4 dari 10 faktor yang digunakan yaitu variabel jaringan irigasi, modal, pupuk dan sumberdaya manusia dan cluster III yaitu kawasan pertanian sangat kurang berkembang karena memiliki skor yang rendah pada 5 atau lebih dari 10 faktor yang digunakan [4]

Sehingga untuk dapat meningkatkan perkembangan potensi produksi komoditas unggulan desa-desa tertinggal di Kabupaten Bangkalan diperlukan analisis mengenai faktorfaktor yang mempengaruhi perkembangan produksi komoditas unggulan desa-desa tertinggal di Kabupaten Bangkalan. Disamping itu juga diperlukan analisis terkait kondisi eksisting dari masing-masing faktor yang mempengaruhi perkembangan produksi komoditas unggulan di masingmasing desa tertinggal untuk mengetahui tingkat perkembangan dari potensi pertanian yang ada disana.

Sebagai daerah yang potensial untuk kegiatan on farm komoditas unggulan, terdapat beberapa hal yang perlu diperhatikan untuk meningkatkan produktivitas dari desa-desa tertinggal itu sendiri, seperti daya dukung sumber daya alam dan potensi fisik kawasan, perbandingan luas kawasan dengan jumlah penduduk yang ideal untuk membangun sistem dan usaha agribisnis pada jenis usaha tertentu, tersedianya prasarana dan sarana produksi dasar yang memadai, adanya lokasi yang berpotensi untuk dikembangkan sebagai pusat pelayanan, penghubung dengan daerah sekitarnya secara terintegrasi [5]. Sedangkan untuk dapat mengembangkan komoditas unggulan di suatu wilayah,maka diperlukan adanya potensi sumber daya alam, sumber daya manusia yang memadai, kelembagaan, iklim usaha, serta kondisi Prasarana dan Sarana Dasar [6]. Pendapat lain menyatakan bahwa pengembangan kawasan yang memiliki potensi komoditas unggulan dilakukan melalui pengembangan dari hal-hal teknis yang meliputi kondisi tanah dan iklim, sosial ekonomi dan kelembagaan yang meliputi penguasaan teknologi, kemampuan sumber daya manusia, infrastruktur dan kondisi 
budaya setempat [7]. Disamping itu pengembangan komoditas unggulan juga dipengaruhi oleh keterkaitan kegiatan on farm dan off farm, aksesibilitas, kelembagaan, kebijakan pemerintah, modal dan kemitraan. [8]

Ditinjau dari tahap perkembangannya, kawasan pertanian dapat diklasifikasikan dalam tiga katagori kelas kawasan yaitu kawasan yang belum berkembang, kawasan yang cukup berkembang, dan kawasan yang telah berkembang. Klasifikasi tersebut didasarkan pada beberapa hal yaitu dominasi kegiatan pertanian on farm/off farm yang ada disana, teknologi budidaya, kelembagaan pertanian, pemasaran, sarana dan prasarana penunjang, serta jenis-jenis kegiatan pelatihan yang dibutuhkan [9]

\section{METODE PENELITIAN}

Pendekatan penelitian yang digunakan adalah pendekatan rasionalistik yaitu pendekatan yang bersumber dari teori dan kebenaran empirik. Pendekatan indigunakan untuk meneliti subjek kajian dengan menekankan pada pemaknaan empirik, pemahaman intelektual serta kemampuan berargumen secara logis dan didukung data-data empirik yang relevan [8]. Sedangkan metode penelitian yang digunakan pada penelitian ini adalah metode penelitian campuran (mixed methods) merupakan sebuah desain penelitian yang melibatkan asumsi filosofi yang menetukan teknik pengumpulan dan analisis data melalui proses campuran kualitatif dan kuantitatif [10]

Indikator dan varibael yang digunakan dalam penelitian ini meliputi indikator potensi fisik dengan variabel jenis tanah, ketinggian tanah, luas lahan pertanian; indikator sumber daya manusia dengan variabel jumlah penduduk yang bekerja sebagai petani, tingkat keterampilan penduduk dalam bertani, dan tingkat pendidikan penduduk; indikator prasarana produksi komoditas unggulan pertanian dengan variabel jaringan jalan, jaringan irigasi, listrik dan air bersih; indikator teknologi pertanian dengan variabel bibit unggul, pupuk, pestisida, dan trator; indikator keterkaitan fugsional dengan variabel hubungan antara kawasan pusat agropolitan dan desa tertinggal sebagai kawasan hinterlandnya; indikator kelembagaan dengan variabel kelompok tani dan KUD; indikator kemitraan dengan variabel kemitraan dengan pemerintah dan kemitraan dengan swasta; serta indikator modal dengan variabel kemudahan mendapatkan bantuan modal dan kepemilikan modal.

Penelitian ini akan menggunakan metode pengumpulan data primer melalui penyebaran kuesioner dengan pendekatan skala linkert dengan ketentuan nilai $1-4,1$ menunjukkan nilai paling buruk dan 4 nilai paling baik. Kuesioner ini disebarkan kepada responden yang menjadi sampel dari populasi penelitian yaitu masyarakat yang bekerja di sektor pertanian pada masing-masing desa tertinggal. Teknik sampling yang digunakan dalam penelitian ini adalah teknik purposive sampling, yaitu teknik untuk menentukan sampel penelitian dengan beberapa pertimbangan tertentu yang bertujuan agar data yang diperoleh bisa lebih representatif [11], sehingga dari teknik sampling ini diketahui sampel yang akan digunakan dalam penelitian ini adalah sampel penduduk yang bekerja pada kegiatan produksi komoditas unggulan pertanian di masing-masing desa tertinggal dengan jumlah responden sebanyak 1 orang/desa untuk mengindentifikasi faktor-faktor yang mempengaruhi perkembangan potensi produksi komoditas unggulan pertanian desa-desa tertinggal, sedangkan untuk melakukan analisis terhadap kondisi eksisting yang akan digunakan sebagai input untuk analisis cluster sebanyak 4 orang/desa.

Untuk melakukan identifikasi faktor-faktor yang mempengaruhi perkembangan produksi komoditas unggulan, teknik analisis yang digunakan adalah teknik analisis confirmatory factor analysis (CFA), sedangkan untuk melakukan pengelompokkan (clustering) terhadap kondisi eksisting dari perkembangan produksi komoditas unggulan berdasarkan faktor-faktor yang mempengeruhinya dilakukan dengan analisis cluster

\section{A. Confirmatory Faktor Analysis (CFA)}

CFA adalah salah satu metode analisis faktor yang digunakan ketika peneliti telah memiliki pengetahuan mengenai struktur suatu faktor laten. Struktur faktor laten tersebut diperoleh berdasarkan kajian teoritis, hasil penelitian atau hipotesi peneliti mengenai hubungan antara variabel yang diobservasi dengan variabel laten. Akan tetapi, karena data untuk melakukan analisis CFA ini didapatkan dari hasil kuesioner maka harus dilakukan uji validitas dan reliabilitas terlebih dahulu terhadap kuesioner yang telah disusun. Uji validitas adalah uji untuk mengukur tingkat keabasahan suatu alat ukur yang digunakan, sedangkan uji reliabilitas adalah uji terhadap konsistensi dari hasil kuesioner [11]. Untuk mengetahui mekanisme analisis CFA dapat dilihat pada skema dibawah ini

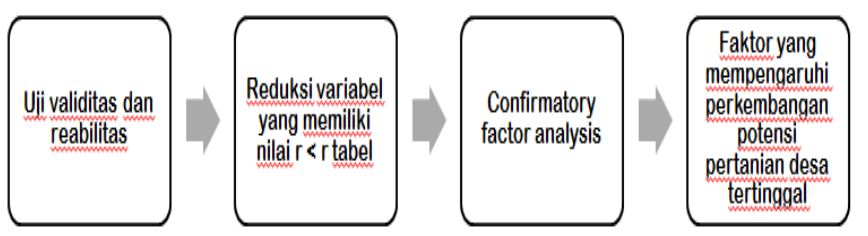

Gambar 1. Skema alur analisis faktor pengembangan potensi pertanian desa tertinggal di Kabupaten Bangkalan.

\section{B. Analisis cluster}

Analisis cluster sendiri merupakan teknik multivarian yang mempunyai tujuan untuk mengelompokkan obyek-obyek berdasarkan karakteristik yang dimilikinya. Analisis cluster mengklasifikasikan obyek sehingga setiap obyek yang memiliki kesamaan dengan obyek lainnya akan dikelompokkan kedalam cluster yang sama. Cluster-cluster yang terbentuk memiliki homogenitas internal (kesamaan antar anggota dalam satu cluster) yang tinggi dan heterogenitas eksternal (perbedaan antara cluster yang satu dengan yang lain tinggi) [11]. Penelitian ini menggunakan metode agglomerative hierarchical cluster analisis yang melakukan proses clustering dari $\mathrm{N}$ cluster menjadi 1 kesatuan cluster, dimana $\mathrm{N}$ adalah jumlah data

\section{ANALISIS DAN PEMBAHASAN}

\section{A. Uji Validitas dan Reabilitas}

Untuk metode pengumpulkan data dengan menggunakan kuesioner, maka diperlukan uji validitas dan uji reabilitas terhadap masing-masing variabel penelitian. Variabel penelitian dianggap valid dan reliabel jika memiliki nilai 
hitung > nilai $r$ tabel, dimana nilai $r$ tabel untuk 36 respondedn dengan tingkat error sebesar $1 \%$ adalah 0.2785 . untuk mengetahui hasil uji validitas dan reabilitas dapat dilihat pada tabel berikut.

Tabel 1.

Uji validitas dan reabilitas terhadap variabel penelitian

\begin{tabular}{|c|c|c|c|c|}
\hline Variabel yang diukur & r hitung & $\begin{array}{l}\text { Cron- } \\
\text { bach's } \\
\text { Alpha }\end{array}$ & R tabel & "Keterangan \\
\hline \multicolumn{5}{|l|}{ Potensi fisik } \\
\hline Jenis tanah & -0.21 & \multirow{2}{*}{0.355} & \multirow{2}{*}{0.2785} & \multirow{2}{*}{$\begin{array}{l}\text { Tidak valid } \\
\text { dan tidak } \\
\text { reliable }\end{array}$} \\
\hline Ketinggian tanah & -0.92 & & & \\
\hline Luas lahan pertanian & 0.859 & \multirow[t]{3}{*}{0.355} & \multirow[t]{3}{*}{0.2785} & \multirow{3}{*}{$\begin{array}{l}\text { Valid dan } \\
\text { reliable }\end{array}$} \\
\hline Kesuburan lahan & 0.811 & & & \\
\hline Sumber daya manusia & & & & \\
\hline $\begin{array}{l}\text { Jumlah penduduk } \\
\text { yang bekerja sebagai } \\
\text { petani }\end{array}$ & 0.476 & \multirow[t]{3}{*}{0.619} & \multirow[t]{3}{*}{0.2785} & \multirow[t]{3}{*}{$\begin{array}{l}\text { Valid dan } \\
\text { reliable }\end{array}$} \\
\hline $\begin{array}{l}\text { Keterampilan dalam } \\
\text { bertani }\end{array}$ & 0.859 & & & \\
\hline $\begin{array}{l}\text { Tingkat pendidikan } \\
\text { penduduk yang } \\
\text { bekerja sebagai } \\
\text { petani }\end{array}$ & 0.361 & & & \\
\hline \multicolumn{5}{|c|}{ Prasarana produksi komoditas unggulan pertanian } \\
\hline $\begin{array}{l}\text { Ketersediaan Jaringan } \\
\text { jalan }\end{array}$ & 0.859 & \multirow[t]{6}{*}{0.536} & \multirow[t]{6}{*}{0.2785} & \multirow[t]{2}{*}{$\begin{array}{l}\text { Valid dan } \\
\text { reliable }\end{array}$} \\
\hline $\begin{array}{l}\text { Ketersediaan Jaringan } \\
\text { irigasi }\end{array}$ & 0.678 & & & \\
\hline Ketersediaan Listrik & -0.033 & & & Tidak valid \\
\hline Ketersediaan Air & 0.154 & & & dan tidak \\
\hline Bersih & & & & reliable \\
\hline \multicolumn{3}{|l|}{ Teknologi pertanian } & & \\
\hline $\begin{array}{l}\text { Ketersediaan bibit } \\
\text { unggul }\end{array}$ & 0.737 & \multirow[t]{4}{*}{0.518} & \multirow[t]{4}{*}{0.2785} & \multirow[t]{2}{*}{$\begin{array}{l}\text { Valid dan } \\
\text { reliable }\end{array}$} \\
\hline Ketersediaan pupuk & 0.300 & & & \\
\hline $\begin{array}{l}\text { Ketersediaan } \\
\text { pestisida }\end{array}$ & 0.264 & & & $\begin{array}{l}\text { Tidak valid } \\
\text { dan tidak } \\
\text { reliable }\end{array}$ \\
\hline Ketersediaan Traktor & 0.468 & & & $\begin{array}{l}\text { Valid dan } \\
\text { reliable }\end{array}$ \\
\hline \multicolumn{5}{|l|}{ Keterkaitan fungsional } \\
\hline $\begin{array}{l}\text { Penjualan hasil } \\
\text { produksi ke pusat } \\
\text { agropolitan }\end{array}$ & 0.618 & \multirow[t]{3}{*}{0.633} & \multirow[t]{3}{*}{0.2785} & \multirow[t]{3}{*}{$\begin{array}{l}\text { Valid dan } \\
\text { reliable }\end{array}$} \\
\hline $\begin{array}{l}\text { Jarak desa tertinggal } \\
\text { ke pusat agropolitan }\end{array}$ & 0.304 & & & \\
\hline Kelembagaan & & & & \\
\hline Kelompok tani & 0.528 & \multirow[t]{3}{*}{0.593} & \multirow[t]{3}{*}{0.2785} & \multirow{3}{*}{$\begin{array}{l}\text { Valid dan } \\
\text { reliable }\end{array}$} \\
\hline KUD & 0.658 & & & \\
\hline $\begin{array}{l}\text { Kemitraan } \\
\text { Kemitraan denoan }\end{array}$ & 0.542 & & & \\
\hline pihak pemerintah & & \multirow{3}{*}{0.688} & \multirow{3}{*}{0.2785} & \multirow{3}{*}{$\begin{array}{l}\text { Valid dan } \\
\text { reliabel }\end{array}$} \\
\hline $\begin{array}{l}\text { Kemitraan dengan } \\
\text { pihak swasta }\end{array}$ & 0.564 & & & \\
\hline Modal & & & & \\
\hline $\begin{array}{l}\text { Kemudahan } \\
\text { mendapatkan bantuan } \\
\text { modal }\end{array}$ & 0.306 & \multirow[t]{2}{*}{0.435} & \multirow[t]{2}{*}{0.2785} & $\begin{array}{l}\text { Valid dan } \\
\text { reliable }\end{array}$ \\
\hline $\begin{array}{l}\text { Persentase } \\
\text { kepemilikian modal } \\
\text { pribadi }\end{array}$ & 0.542 & & & \\
\hline
\end{tabular}

Berdasarkan tabel diatas diketahui bahwa 5 variabel yang akan digunakan merupakan variabel yang tidak valid dan tidak reliabel sehingga tidak bisa digunakan sebagai variabel penelitian.

\section{B. Analisis faktor dengan menggunakan metode CFA}

Analisis faktor ini bertujuan untuk mengetahui faktor-faktor yang mempengaruhi perkembangan produksi komoditas unggulan Desa-desa tertinggal di Kabupaten Bangakalan. Variabel dan indikator yang dianalisis adalah variabel dan indikator yang valid dan reliabel berdasarakn uji validitas dan uji reabilitas yang telah dilakukan sebelumnya. Analisis CFA ini disamping menentukan faktor-faktor yang berpengaruh melalui perhitungan KMO dan uji signifikansi, juga mengkonfirmasi variabel-variabel apa saja yang termasuk ke dalam faktor-faktor tersebut melalui perhitungan nilai MSA. Faktor yang bisa digunakan dalam analisis ini adalah faktor yang memiliki nilai $\mathrm{KMO} \geq 0.5$ dan nilai signifikansi $<0.05$ [12]. Nilai $\mathrm{KMO} \geq 0.5$, mengindikasikan bahwa faktor dan variabel tersebut bisa digunakan untuk dianalisis lebih lanjut, sedangkan nilai signifikansi $<0.05$ menunjukkan adanya korelasi yang signifikansi antar variabel di dalam faktor tersebut. Untuk mengetahui faktor-faktor yang mempengaruhi perkembangan produksi komoditas unggulan di desa-desa tertinggal di Kabupaten Bangkalan dapat dilihat pada tabel dibawah ini.

Tabel 2.

Hasil analisis CFA terhadap faktor yang mempengaruhi perkembangan potensi produksi kemoditas unggulan pertanian desa-desa tertinggal di Kabupaten Bangkalan

\begin{tabular}{lccc}
\hline \hline \multicolumn{1}{c}{ Faktor } & KMO & Signifikansi & Keterangan \\
\hline Potensi fisik & 0.500 & 0.000 & Berpengaruh \\
Sumber daya manusia & 0.564 & 0.008 & $\begin{array}{c}\text { Berpengaruh } \\
\text { Prasarana produksi }\end{array}$ \\
komoditas unggulan & 0.500 & 0.000 & Berpengaruh \\
pertanian & & & \\
Teknologi pertanian & 0,641 & 0.013 & Berpengaruh \\
Keterkaitan fungsional & 0.500 & 0.001 & Berpengaruh \\
Kelembagaan & 0.500 & 0.003 & Berpengaruh \\
Kemitraan & 0.500 & 0.000 & Berpengaruh \\
Modal & 0.500 & 0.035 & Berpengaruh \\
\hline Sumber: Hasil analisis, 2017 & & &
\end{tabular}

Berdasarkan tabel diatas diketahui bahwa terdapat keseluran faktor yang dianalisis merupakan faktor -faktor yang mempengaruhi perkembangan produksi komoditas unggulan pertanian desa-desa tertinggal di Kabupaten Bangkalan. Sedangkan variabel-variabe yang berperngaruh terhadap perkembangan produksi komoditas unggulan ditentukan oleh variabel dengan nilai MSA $\geq 0.5$. untuk mengetahui variabel-variabel yang berpengaruh terhadap perkembangan produksi komoditas unggulan desa-desa tertinggal di Kabupaten Bangkalan dapat dilihat pada tabel berikut.

Tabel 3.

Hasil Analisis CFA terhadap variabel yang berpengaruh terhadap perkembangan produksi komoditas unggulan pertanian desa-desa tertinggal di Kabupaten Bangkalan

\begin{tabular}{lcc}
\hline \hline Variabel yang diukur & Nilai MSA & Keterangan \\
\hline $\begin{array}{l}\text { Potensi fisik } \\
\text { Luas lahan pertanian }\end{array}$ & 0.500 & Berpengaruh \\
$\begin{array}{l}\text { Kesuburan lahan } \\
\text { Sumber daya manusia }\end{array}$ & 0.500 & \\
$\begin{array}{l}\text { Jumlah penduduk yang bekerja sebagai } \\
\text { petani }\end{array}$ & 0.542 & Berpengaruh \\
$\begin{array}{l}\text { Keterampilan dalam bertani } \\
\text { Tingkat pendidikan penduduk yang } \\
\text { bekerja sebagai petani }\end{array}$ & 0.584 & \\
$\begin{array}{l}\text { Prasarana produksi komoditas unggulan pertanian } \\
\text { Ketersediaan Jaringan jalan }\end{array}$ & 0.584 & \\
& 0.500 & Berpengaruh
\end{tabular}




\begin{tabular}{lll}
\hline \hline Variabel yang diukur & Nilai MSA & Keterangan \\
\hline $\begin{array}{l}\text { Ketersediaan Jaringan irigasi } \\
\text { Teknologi pertanian }\end{array}$ & 0.500 & \\
$\begin{array}{l}\text { Ketersediaan bibit unggul } \\
\text { Ketersediaan pupuk }\end{array}$ & 0.624 & Berpengaruh \\
$\begin{array}{l}\text { Ketersediaan Traktor } \\
\text { Keterkaitan fungsional }\end{array}$ & 0.624 & \\
$\begin{array}{l}\text { Penjualan hasil produksi ke pusat } \\
\text { agropolitan }\end{array}$ & 0.690 & \\
$\begin{array}{l}\text { Jarak desa tertinggal ke pusat agropolitan } \\
\text { Kelembagaan }\end{array}$ & 0.500 & Berpengaruh \\
$\begin{array}{l}\text { Kelompok tani } \\
\text { KUD }\end{array}$ & 0.500 & \\
$\begin{array}{l}\text { Kemitraan } \\
\text { Kemitraan dengan pihak pemerintah }\end{array}$ & 0.500 & Berpengaruh \\
$\begin{array}{l}\text { Kemitraan dengan pihak swasta } \\
\text { Modal }\end{array}$ & 0.500 & \\
$\begin{array}{l}\text { Kemudahan mendapatkan bantuan modal } \\
\text { Persentase kepemilikian modal pribadi }\end{array}$ & 0.500 & Berpengaruh \\
\hline \hline
\end{tabular}

Berdasarkan hasil analisis CFA pada tabel diatas, diketahui bahwa semua variabel yang valid dan reliabel merupakan variabel yang berpengaruh terhadap perkembagan potensi produksi komoditas unggulan desa tertinggal di Kabupaten Bangkalan karena memiliki nilan MSA $\geq 0.5$. sehingga faktorfaktor yang berpengaruh terhadap perkembangan potensi komoditas unggulan desa-desa tertinggal di Kabupaten Bangkalan adalah sebagai berikut

\section{Tabel 4.}

Faktor yang berpengaruh terhadap perkembangan potensi komoditas unggulan desa-desa tertinggal di Kabupaten Bangkalan

\begin{tabular}{|c|c|}
\hline Faktor & Variabel \\
\hline Potensi fisik & $\begin{array}{l}\text { Luas lahan pertanian } \\
\text { Kesuburan lahan }\end{array}$ \\
\hline Sumber daya manusi & $\begin{array}{l}\text { Jumlah penduduk yang bekerja sebagai petani } \\
\text { Keterampilan penduduk dalam bertani } \\
\text { Tingkat pendidikan petani }\end{array}$ \\
\hline Prasarana produksi & Ketersediaan Jaringan jalan \\
\hline $\begin{array}{l}\text { komoditas unggulan } \\
\text { pertanian }\end{array}$ & Ketersediaan Jaringan irigasi \\
\hline $\begin{array}{l}\text { Teknologi } \\
\text { pertanian }\end{array}$ & $\begin{array}{l}\text { Ketersediaan bibit unggul } \\
\text { Ketersediaan Pupuk } \\
\text { Ketersediaan Traktor }\end{array}$ \\
\hline Keterkaitan fungsional & $\begin{array}{l}\text { Penjualan hasil produksi ke pusat agropolitan } \\
\text { Jarak desa tertinggal ke pusat agropolitan }\end{array}$ \\
\hline Kelembagaan & $\begin{array}{l}\text { Jumlah dan peran Kelompok tani } \\
\text { Jumlah dan peran KUD }\end{array}$ \\
\hline Kemitraan & $\begin{array}{l}\text { Kemitraan dengan pihak pemerintah } \\
\text { Kemitraan dengan pihak swasta }\end{array}$ \\
\hline Modal & $\begin{array}{l}\text { Kemudahan mendapatkan modal } \\
\text { Persentase kepemilikan modal pribadi }\end{array}$ \\
\hline
\end{tabular}

\section{Analisis Cluster}

Analisis cluster ini bertujuan untuk mengelompokka (clustering) desa tertinggal berdasarkan perkembangan potensi produksi komoditas unggulannya, melalui penilaian terhadap kondisi eksisting dari masing-masing faktor yang mempengaruhi perkembangan produksi komoditas unggulan pertanian desa tertinggal di Kabupaten Bangkalan. Melalui analisis cluster ini akan mengelompokkan data yang mirip dalam hierarki yang sama sedangkan yang tidak mirip ke dalam hierarki yang berbeda. Untuk mengetahui hasil dari hierchical cluster analisis dari masing-masing desa tertinggal tersebut berdasarkan perkembangan potensi produksi komoditas unggulan pertaniannya dapat dilihat pada dendogram berikut

\begin{tabular}{|c|}
\hline Morombuh \\
\hline Baipajung \\
\hline Laranqan Sorjan \\
\hline Kompol \\
\hline Batah Barat \\
\hline Janteh \\
\hline Makam Aqung \\
\hline Pa'kaan Laok \\
\hline Lantek Barat \\
\hline Kajuanak \\
\hline Banjar \\
\hline Sumar Kaning \\
\hline Tanah Merah Laok \\
\hline Poter \\
\hline Batah Timar \\
\hline Pangpajung \\
\hline Kampak \\
\hline Banyior \\
\hline Blegaholoh \\
\hline Campor \\
\hline Manonggal \\
\hline $\mathrm{Ko}$ '0l \\
\hline Lembang Paseser \\
\hline Ra'as \\
\hline Dapok \\
\hline Tambak Pocok \\
\hline Kombanqan \\
\hline Benangkah \\
\hline Panggolangan \\
\hline Bulnh \\
\hline Kapor \\
\hline Arok \\
\hline
\end{tabular}

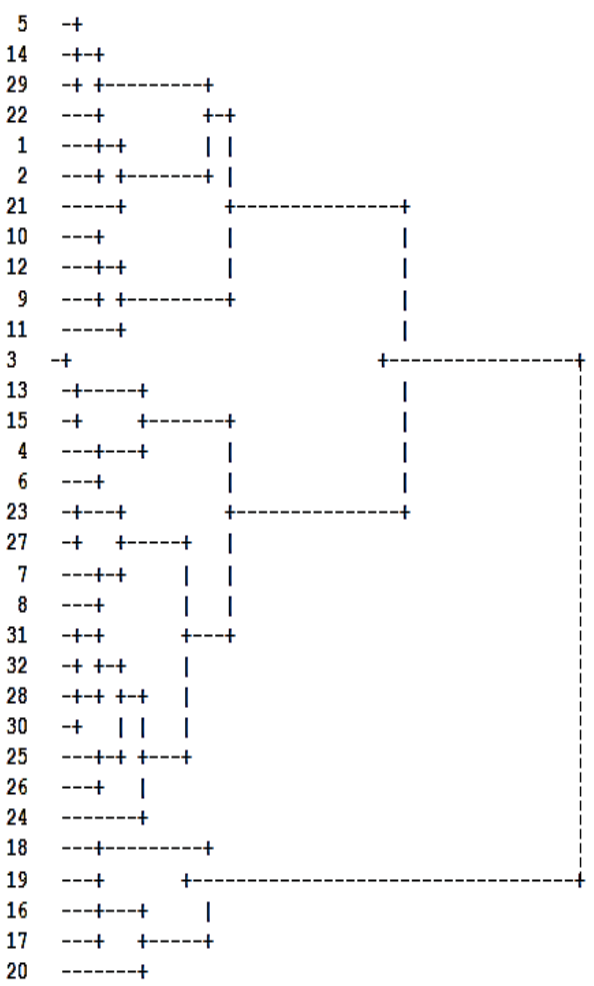

Gambar 2. Dendogram hierarchical cluster analisis desa tertinggal berdasarkan perkembangan pertaniannya.

Tabel 5.

Desa-desa tertinggal berdasarkan cluster perkembangan potensi produksi komoditas unggulan pertaniannya

\begin{tabular}{lll}
\hline \hline Cluster 1 & Cluster 2 & Cluster 3 \\
\hline 1. Batah Barat & 1. Sumur Kuning & 1. Buluh \\
2. Janteh & 2. Batah Timur & 2. Kapor \\
3. Morombuh & 3. Pangpajung & 3. Benangkah \\
4. Kajuanak & 4. Blegaholoh & 4. Panggolangan \\
5. Pa'akan Laok & 5. Campor & 5. Arok \\
6. Banjar & 6. Tanah Merah Laok & \\
7. Lantek Barat & 7. Poter & \\
8. Baipajung & 8. Kampak & \\
9. Makam Agung & 9. Kombangan & \\
10.Kompol & 10. Dupok & \\
11.Larangan Sorjan & 11. Tambak Pocok & \\
& 12. Banyior & \\
& 13. Lembung Paseser & \\
& 14. Ra'as & \\
& 15. Manonggal & \\
\hline \hline
\end{tabular}

Berdasarkan tabel diatas, diketahui bahwa terdapat 11 desa yang termasuk ke dalam cluster 1, 16 desa yang termasuk ke dalam cluster 2 dan 5 desa yang termasuk ke dalam cluster 3 . Berdasarkan hasil analisis terhadap kondisi eksisting dari masing-masing cluster, maka dapat diketahui karakteristik dari masing-masing cluster adalah sebagai berikut

Tabel 5.

Karakteristik masing-masing cluster berdasarkan perkembangan potensi produksi pertaniannya

\begin{tabular}{lll}
\hline \hline \multicolumn{1}{c}{ Cluster 1 } & \multicolumn{1}{c}{ Cluster 2 } & \multicolumn{1}{c}{ Cluster 3 } \\
\hline Luasan lahan & Luasan lahan pertanian & Luasan lahan pertanian \\
pertanian untuk & untuk masing-masing & untuk masing-masing \\
masing-masing RTP & RTP sudah cukup & RTP sudah cukup \\
kecil sehingga & memadai sehingga & memadai sehingga \\
produksinya terbatas & produksinya bisa & produksinya bisa \\
& memenuhi kebutuhan & memenuhi kebutuhan \\
\hline \hline
\end{tabular}




\begin{tabular}{|c|c|c|}
\hline & $\begin{array}{l}\text { keluarga dan sebagian } \\
\text { dijual }\end{array}$ & $\begin{array}{l}\text { keluarga dan sebagian } \\
\text { besar dijual }\end{array}$ \\
\hline $\begin{array}{l}\text { Masih diperlukannya } \\
\text { pendampingan dari } \\
\text { penyuluh dalam hal } \\
\text { budidaya }\end{array}$ & $\begin{array}{l}\text { Masih diperlukannya } \\
\text { pendampingan dari } \\
\text { penyuluh pertanian } \\
\text { dalam hal budidaya }\end{array}$ & $\begin{array}{l}\text { Masih diperlukannya } \\
\text { pendampingan dari } \\
\text { penyuluh pertanian dalam } \\
\text { hal pengolahan dan } \\
\text { pemasaran }\end{array}$ \\
\hline $\begin{array}{l}\text { Irigasi tadah hujan } \\
\text { sehingga } \\
\text { ketergantugan } \\
\text { terhadap alam masih } \\
\text { tinggi }\end{array}$ & $\begin{array}{l}\text { Terdapat saluran irigasi } \\
\text { yang memadai, akan } \\
\text { tetapi diperlukan } \\
\text { peningkatan fungsi dan } \\
\text { pelayananya }\end{array}$ & $\begin{array}{l}\text { Jaringan irigasi sudah } \\
\text { ada, namun perlu } \\
\text { ditingkatkan lagi } \\
\text { pelayanannya }\end{array}$ \\
\hline $\begin{array}{l}\text { Teknologi pertanian } \\
\text { masih kurang } \\
\text { memadai }\end{array}$ & $\begin{array}{l}\text { Teknologi pertanian } \\
\text { masih kurang memadai }\end{array}$ & $\begin{array}{l}\text { Teknologi pertanian yang } \\
\text { digunakan sudah cukup } \\
\text { memadai }\end{array}$ \\
\hline $\begin{array}{l}\text { Kelembagaan } \\
\text { pertanian dan KUD } \\
\text { kurang berperan }\end{array}$ & $\begin{array}{l}\text { Kelembagaan } \\
\text { pertanian dan KUD } \\
\text { kurang berperan }\end{array}$ & $\begin{array}{l}\text { Kelembagaan pertanian } \\
\text { yang meliputi kelompok } \\
\text { tani sudah mulai mampu } \\
\text { berperan aktif }\end{array}$ \\
\hline
\end{tabular}

Berdasarkan karakteristik dan ciri-ciri dari masing-masing cluster tersebut, maka dapat disimpulkan bahwa perkembangan potensi pertanian pada desa-desa tertinggal di cluster 1 kondisinya lebih tidak berkembang dibandingkan dengan cluster 2, begitu pula dengan cluster 2 yang kondisinya lebih tidak berkembang dibandingkan dengan cluster 3 . Perkembangan kawasan pertanian dibedakan menjadi 3 cluster yaitu belum berkembang, cukup berkembang dan sudah berkembang [9]. Sehingga Kelas kawasan ini bisa menjadi salah satu indikator dari perkembangan potensi pertanian karena memiliki beberapa fokusan karakteristik yang sama seperti penilaian terhadap teknologi pertanian, sarana dan prasarana penunjang pertanian, dan pengembangan sumber daya manusia, sehingga bisa digunakan sebagai acuan untuk memberikan penamaan pada cluster yang telah terbentuk dari hasil analisis yaitu sebagai berikut:

a. Cluster $1=$ Desa dengan perkembangan potensi produksi pertanian yang sangat belum berkembang

b. Cluster $2=$ Desa dengan perkembangan potensi produksi pertanian yang belum berkembang

c. Cluster $3=$ Desa dengan perkembangan potensi produksi pertanianyang cukup berkembang

Untuk mengetahui desa-desa tertinggal mana saja yang termasuk kedalam cluster 1 , cluster 2 dan cluster 3 dapat dilihat pada peta berikut.

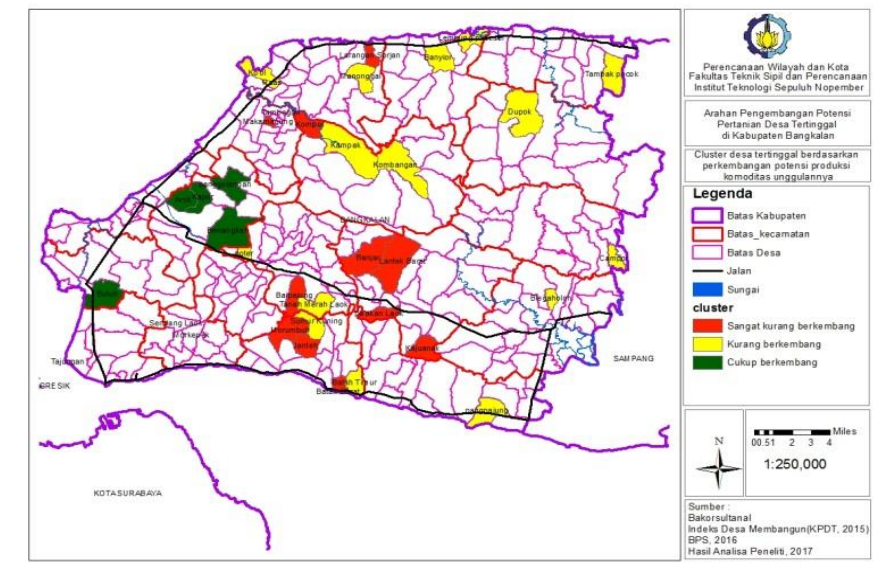

Gambar 3. peta persebarana desa tertinggal berdasarkan cluster perkembangan potensi produksi komoditas unggulan pertaniannya.

\section{KESIMPULAN/RINGKASAN}

Berdasarkan hasil analisis diketahui bahwa faktor-faktor yang mempengaruhi perkembangan potensi pertanian desa tertinggal di Kabupaten Bangkalan adalah potensi fisik, sumber daya manusia, prasarana produksi komoditas unggulan pertanian, teknologi pertanian, keterkaitan fungsional, kelembagaan, kemitraan dan modal. Sedangkan berdasarkan analisis cluster terhadap kondisi eksisting dari masing-masing faktor tersebut, desa-desa tertinggal di Kabupaten Bangkalan terbagi ke dalam 3 cluster yaitu cluster I (desa tertinggal dengan perkembangan potensi pertanian sangat kurang berkembang) sebanyak 11 desa, cluster II (desa tertinggal dengan perkembangan potensi pertanian kurang berkembang) sebanyak 16 desa dan cluster III cluster I (desa tertinggal dengan perkembangan potensi pertanian cukup berkembang) sebanyak 5 desa.

\section{DAFTAR PUSTAKA}

[1] KPDT, Indeks Desa Membangun. Jakarta: KPDT, 2015.

[2] BPS, Kabupaten BangkalanDalam Angka Tahun 2016. Bangkalan: BPS Kabupaten Bangkalan, 2016.

[3] B. Oksatriandhi, "Identifikasi Komoditas Unggulan di Kawasan Agropolitan Kabupateen Pasaman," J. Tek. Pomits, vol. 3, no. 1, 2014.

[4] E. K. Dewi, "Arahan Pengembangan Kawasan Pertanian di Kabupaten Bangkalan," 2009.

[5] D. Pertanian, Pedoman Pengembangan Kawasan Pertanian Berkelanjutan. Jakarta, 2012.

[6] C. Karya, Agropolitan Dan Minapolitan Konsep Kawasan Menuju Keharmonisan. Jakarta, 2012.

[7] H. I. Permata, "Arahan Pengembangan Komoditas Unggulan di KabuPaten Muara Enim Sumatera Selatan," J. Tek. Pomits, vol. 3, no. 2, 2014.

[8] S. D. A. Wantika, "Faktor-Faktor Yang Mempengaruhi Pengembangan Komoditas Unggulan Hortikultura Di Kawasan Agropolitan Ngawasondat Kabupaten Kediri," J. Tek. Pomits, vol. 5, no. 1, 2016.

[9] K. Pertanian, Permentan Nomor 50 Tahun 2012 Tentang Pedoman Pengembangan Kawasan Pertanian. Jakarta: Kemeterian Pertanian, 2012.

[10] N. Muhadjir, Metode Penelitian Kualitatif. Jakarta, 2000.

[11] Y. Herlanti, Tanya jawab seputar penelitian pendidikan sains. Jakarta, 2014.

[12] Sugiyono, Metode Penelitian Kuantitatif Kualitatif dan $R \& D$. Bandung: Alfabeta, 2010. 